\title{
Ganoderma lucidum Polysaccharides Prevent Palmitic Acid-Evoked Apoptosis and Autophagy in Intestinal Porcine Epithelial Cell Line via Restoration of Mitochondrial Function and Regulation of MAPK and AMPK/Akt/mTOR Signaling Pathway
}

\author{
Zengenni Liang ${ }^{1}$, Zhihang Yuan ${ }^{2}$, Jiajing Guo ${ }^{1}$, Jing $\mathrm{Wu}^{2}$, Jine $\mathrm{Yi}^{2}$, Jing Deng ${ }^{3}$ and \\ Yang Shan ${ }^{3, *}$ \\ 1 Hunan Agricultural Product Processing Institute, Hunan Academy of Agricultural Sciences, \\ Changsha 410125, China; enni_007@163.com (Z.L.); guojiajing2018@163.com (J.G.) \\ 2 College of Veterinary Medicine, Hunan Agricultural University, Changsha 410128, China; \\ zhyuan2016@hunau.edu.cn (Z.Y.); wujing@stu.hunau.edu.cn (J.W.); yijine@stu.hunau.edu.cn (J.Y.) \\ 3 Hunan Academy of Agricultural Sciences, Changsha 410125, China; denging2020@163.com \\ * Correspondence: yangshan2018@stu.hunau.edu.cn; Tel.: +86-731-846-98915
}

Received: 22 December 2018; Accepted: 18 January 2019; Published: 23 January 2019

\begin{abstract}
Ganoderma lucidum polysaccharide (GLP) extracted from Ganoderma lucidum (Leyss. ex Fr.) Karst, a traditional Chinese medicine, is a biologically active substance reported to possess anti-oxidative, anti-apoptotic, and neurological protection. However, it is unknown whether GLP have any protective effect against high-fat constituents-induced epithelial cell injury. The aim of this study was to investigate the protection and molecular mechanism of GLP on injury induced by palmitic acid (PA) in the intestinal porcine epithelial cell line (IPEC-J2). First, we tested whether the treatment of GLP attenuate PA-induced IPEC-J2 cell death. GLP markedly blocked PA-caused cytotoxicity and apoptosis in IPEC-J2 cells. Moreover, GLP recovered the decreased mitochondrial function and inhibited activation of caspase-dependent apoptotic pathway. Interestingly, PA promoted cell apoptosis and autophagy through stimulation of phosphorylation of mitogen-activated protein kinases (MAPKs), AMP-activated protein kinase (AMPK), and inhibition of phosphorylation of Akt and mammalian target of rapamycin (mTOR), which was reversed by GLP. Taken together, this study revealed a protective effect of GLP against PA-evoked IPEC-J2 cell death through anti-apoptotic and anti-autophagic properties.
\end{abstract}

Keywords: Ganoderma lucidum; polysaccharides; apoptosis; autophagy; mitochondria

\section{Introduction}

The intestinal tract is an important organ that controls nutrient digestion and absorption. Nevertheless, it is extremely sensitive to high-fat constituents, and may be impaired by excess intake of high-fat foods though functional and morphological alterations related to intestinal permeability, which lead to malnutrition and inflammatory and metabolic disease [1]. Intestinal epithelial cells (IECs) are firmly organized into a single continuous layer and form the surfaces of the intestine to defend against foreign materials [2]. IECs can respond to a variety of potential risks to maintain organic homeostasis on a continuous basis in the mammalian gastrointestinal tract [3]. Hence, IECs are sentinels in intestinal homeostasis that facilitate the development of new approaches to protect against intestinal diseases [4]. 
It is becoming increasingly recognized that diet quality plays a crucial role in promoting intestinal health. Notably, a high-fat diet (HFD) is an important source of saturated fatty acids (e.g., lard and palmitic acid (PA)) that was found to be a statistically significant risk factor for development of diseases such as obesity, diabetes, angiocardiopathy, hyperproliferation, and cancer [5,6]. Mice exhibited the development of gross intestinal lesions and neoplasia that were histologically categorized as hyperplasia of intestinal mucosa and dysplastic crypts when maintained on the high-fat western-style diet for a duration of twenty-four months without any chemical intervention [7]. These mice also showed a significant enhancement of the short-term mitotic activity in the basal and intermediate portions of the colonic crypts, which simultaneously increased apoptosis of colonic epithelial cells [7].

G. lucidum, a Basidiomycetes mushroom, belongs to the family of Polyporaceae (or Ganodermataceae) of Aphyllophorals that grows in the tropical and subtropical areas of the word. Polysaccharides are one of the main bioactive components of Ganoderma lucidum linked by long-chain sugar molecules and glycosidic bonds. Clinical trials and other experimental studies indicated that Ganoderma lucidum polysaccharide (GLP) are responsible for several biological effects including anti-oxidative, antitumor, and neurological protection, and reportedly exerted significant effects on suppressing obesity and diabetes development $[8,9]$. Intraperitoneal injection of doses of GLP (50 and $100 \mathrm{mg} / \mathrm{kg} / \mathrm{d}$ ) in diabetic mice reduced epididymal fat/body weight ratio and fasting serum glucose levels, which related to low hepatic mRNA expressions of glycogen phosphorylase (GP) and glucose-6-phosphatase (G6Pase) and high mRNA levels of fatty acid synthase, acetyl-CoA carboxylase, and resistin in epididymal fat tissue [10,11]. This evidence indicated that GLP are potentially promising agents for obesity and diabetes therapy. However, to our knowledge, the roles of GLP in modulating high-fat constituents-mediated cell death in the intestinal tract have been poorly understood. Here, we intend to investigate the potential anti-cytotoxicity, anti-apoptotic, and anti-autophagic effects of GLP on PA-induced IPEC-J2 cells and to elucidate in detail the mechanisms underlying signaling pathways responsible for the anti-apoptotic and anti-autophagic role of GLP.

\section{Results}

\subsection{GLP Suppressed PA-Mediated Cell Viability Loss in IPEC-J2 Cells}

When cells were treated with $100,300,600$, and $1200 \mu \mathrm{M}$ PA for $24 \mathrm{~h}$, the inhibitory rate of cell viability was $0,9.8 \%, 50.9 \%$ and $52.0 \%$, respectively, and its IC50 value was $362.8 \mu \mathrm{M}$ (Figure $1 \mathrm{~A}$ ). Since a $24 \mathrm{~h}$ incubation with PA reduced more than $50 \%$ of cell vitality at a concentration of $600 \mu \mathrm{M}$ compared with control, we chose this concentration for subsequent assessments. In order to evaluate the toxicity of GLP, various concentrations of GLP $(0-1.2 \mathrm{mg} / \mathrm{mL})$ were incubated with cells for $24 \mathrm{~h}$, and the cell viability was assayed by MTT. As shown in Figure 1B, treatment of GLP up to $1.2 \mathrm{mg} / \mathrm{mL}$ did not appear to have a negative effect on IPEC-J2 cell viability, suggesting no toxicity at these concentrations to the cells. In particular, high concentrations of GLP $(0.6$ and $1.2 \mathrm{mg} / \mathrm{mL})$ resulted in an obvious increase in cell viability amounting to $139.0 \%$ and $188.0 \%$ of the control group, respectively. The potential protective effect of GLP was also determined in PA-induced IPEC-J2 cells. Figure 1C showed that GLP led to a dose-dependent inhibition of PA-induced cell viability loss $(p<0.01)$. In the presence of PA, high doses of GLP $(0.3-1 \mathrm{mg} / \mathrm{mL})$ stimulated markedly higher cell viability than control in IPEC-J2 cells. 
A

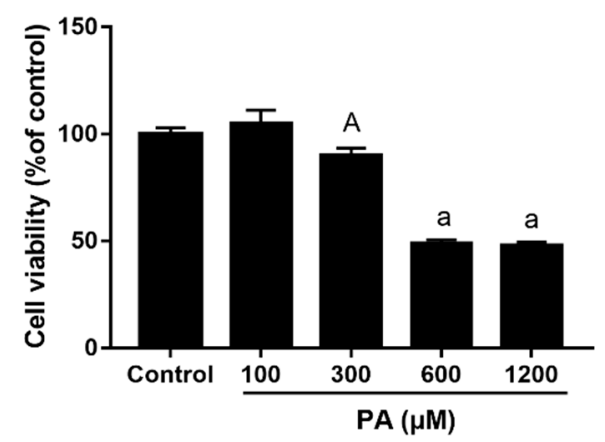

B

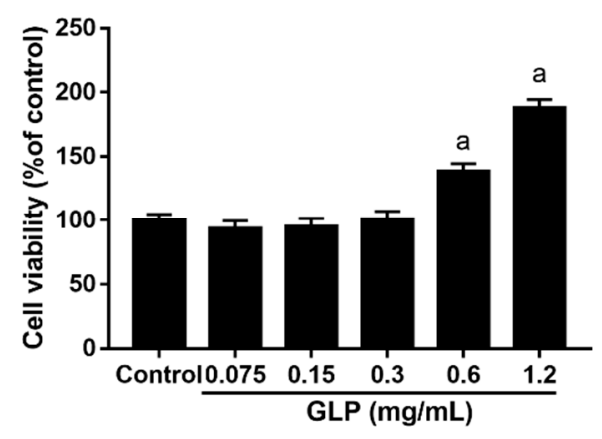

C

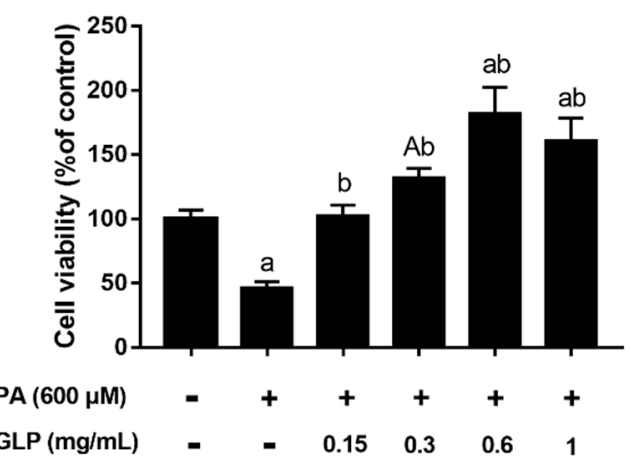

Figure 1. MTT assay determined the effects of palmitic acid (PA) and Ganoderma lucidum polysaccharide (GLP) on IPEC-J2 cell viability. Cells were treated with a 1640 medium containing 10\% FBS (control), various concentrations of PA or/and GLP for $24 \mathrm{~h}$. (A) Dose-dependent inhibitory effect of PA on IPEC-J2 cell viability. (B) The effect of various concentrations GLP $(0.075-1.2 \mathrm{mg} / \mathrm{mL})$ on IPEC-J2 cell viability. (C) The protective effect of GLP on PA-induced cell viability loss. Values are expressed as percentages of control and are as mean \pm SE for three independent experiments $(n=5) . \mathrm{A}<0.05$ and $\mathrm{a}<0.01$ vs. control, $\mathrm{b}<0.01$ vs. PA alone.

\subsection{Effect of GLP on Cell Morphology in PA-Induced IPEC-J2 Cells}

4',6-diamidi-no-2-phenylindole (DAPI) preferentially stains double-stranded DNA (dsDNA) in the nucleus. Consequently, it was usually used to assess cells with typical apoptotic characteristics [12]. As shown in Figure 2A, nuclei of untreated cells with blue fluorescence exhibited intact spherical structures and chromatin homogenously distributed in the nuclei. After cell treatment with $600 \mu \mathrm{M}$ PA for $24 \mathrm{~h}$, a lot of segmented nuclei with significant nuclear shrinkage, chromatin condensation, and fragmentation were observed in cells, as was evidenced by the appearance of prominent blue-colored semilune in PA-induced cells. On GLP treatment, most of cells displayed a spheric shape and uniformly stained chromatin, and the number of cells with chromatin condensation/fragmentation was lower in comparison to PA-treated cells. These results suggest that PA caused cell death by induction of apoptosis while GLP decreased PA-mediated apoptosis in IPEC-J2 cells. 

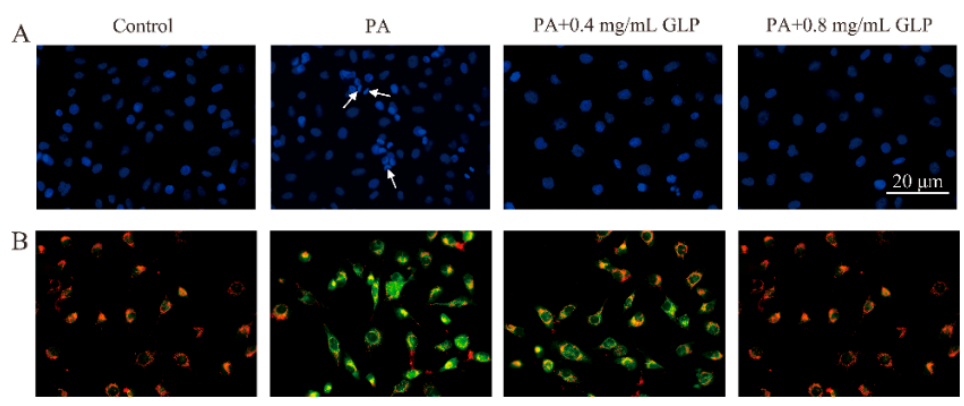

C
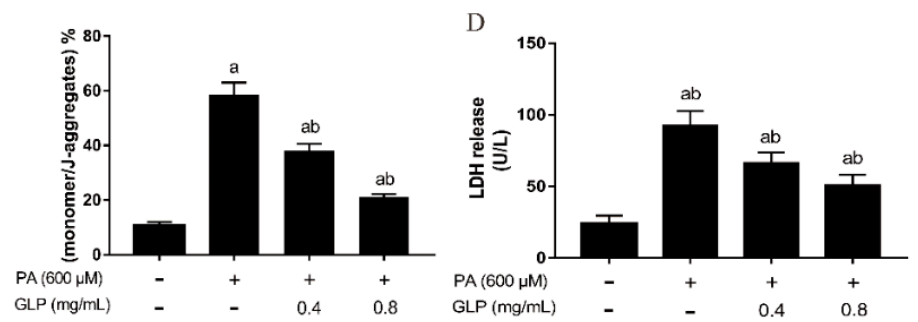

Figure 2. The effects of GLP on apoptotic characteristics in PA-induced IPEC-J2 cells. Cells were exposed to $600 \mu \mathrm{M}$ PA with or without 0.4 and $0.8 \mathrm{mg} / \mathrm{mL}$ of GLP for $24 \mathrm{~h}$. (A) Representative images of 4',6-diamidi-no-2-phenylindole (DAPI) staining (blue). Arrows denote chromatin condensation and fragmentation. Original magnification $400 \times$. (B) The mitochondrial membrane potential was examined by JC-1 staining. JC-1 aggregate and JC-1 monomer exhibited red and green fluorescence, respectively $(400 \times)$. (C) JC-1 staining quantification results are presented as the mean of monomer/J-aggregates \pm SE. (D) The release of LDH was analyzed using a commercially available kit and calculated as U/L. Data were presented as mean \pm SE for three independent experiments $(n=3)$, $\mathrm{a}<0.01$ vs. control, $\mathrm{b}<0.01$ vs. PA alone.

\subsection{GLP Restored PA-Caused Loss of Mitochondrial Membrane Potential in IPEC-J2 Cells}

As shown in Figure 2B,C, untreated cells stained with JC-1 indicated red fluorescence, showing a high mitochondrial membrane potential. Exposure to $600 \mu \mathrm{M}$ PA caused a color change in intracellular fluorescence from red to green in almost cells, suggesting that $\Delta \psi \mathrm{m}$ depolarization led to the monomer concentration reaching a high level. Similar to the effects obtained on MTT assay, cells incubated with GLP in presence of PA exhibited less green fluorescence and more red fluorescence in contrast to the PA-treated cells in dose-dependent manner. Furthermore, cells treated by positive control carbonyl cyanide 3-chlorophenylhydrazone (CCCP) exhibited an intense green fluorescence, indicating that a high depolarization of the mitochondrial membrane has occurred. These results suggest that GLP was capable of attenuating $\Delta \psi \mathrm{m}$ loss and suppressing the mitochondrial response.

\subsection{GLP Alleviated the Increase of LDH Release in PA-Stimulated IPEC-J2 Cells}

$\mathrm{LDH}$ is a hydrogen transfer enzyme, which is used to measure the loss of cellular membrane integrity. To assess the effect of PA and GLP on cellular membrane integrity, LDH activity in cultured cell supernatant was evaluated after cells were incubated with GLP and PA for $24 \mathrm{~h}$. Figure 2D showed the LDH release in untreated, PA-injured, and GLP-protected cells. Cellular LDH release significantly increased to 2.9-fold on $24 \mathrm{~h}$ of $600 \mu \mathrm{M}$ PA incubation compared with that in untreated cells $(p<0.01$; $n=5$ ), indicating a significant cytotoxic effect on cellular membrane integrity induced by PA, whereas GLP and PA co-treatment could dose-dependently decrease an increase of LDH release.

\subsection{GLP Moderated PA-Triggered Apoptosis in IPEC-J2 Cells}

Initially, we performed flow cytometric assay in order to determine whether GLP alleviate PA-induced apoptosis in the target cells. As seen in Figure 3A, $600 \mu \mathrm{M}$ PA caused an almost 7-fold increase in the percentage of apoptotic cells (early and late apoptotic cells) as compared with the 
controls (control, $3.07 \% \pm 0.14 \% ; \mathrm{PA}, 11.81 \% \pm 0.25 \% ; n=3$ ). In contrast, the elevated apoptosis in PA-stressed IPEC-J2 cells was obviously decreased by $32.30 \%$ and $48.06 \%$, respectively, in presence of both GLP and PA $(p<0.01)$.
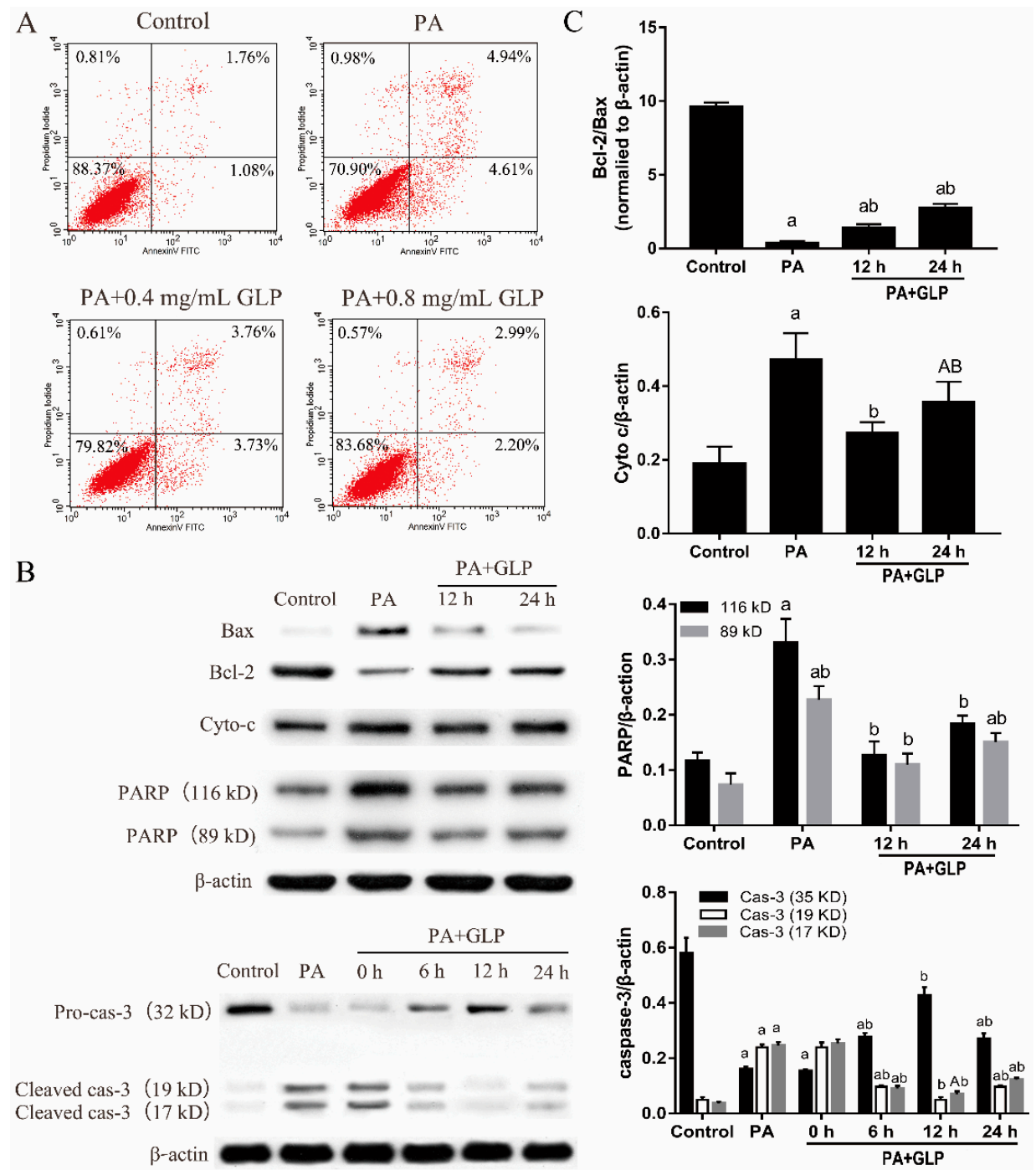

Figure 3. GLP prevented PA-induced apoptosis in IPEC-J2 cells. Cells were exposed to 0.4 and $0.8 \mathrm{mg} / \mathrm{mL}$ GLP in presence of $600 \mu \mathrm{M}$ PA for $24 \mathrm{~h}$. (A) Quantification of IPEC-J2 apoptotic cells by flow cytometry. Four parts were observed: necrotic cells (upper left quadrants), late apoptotic and necrotic cells (upper right quadrants), viable cells (lower left quadrants), and early apoptotic cells (lower right quadrant). (B) The expressions of Bax, Bcl-2, Cyto c, caspase-3 (cas-3), and PARP were analyzed by Western blot. (C) The data were quantified and normalized to $\beta$-actin. Data shown are representative of three independent experiments $(n=3)$. A $<0.05$ and a $<0.01$ vs. control, $\mathrm{B}<0.05$ and $\mathrm{b}<0.01$ vs. PA alone.

The potential molecular mechanisms underlying this protective effect of GLP on PA-induced cell apoptosis were investigated through measuring the expression of apoptosis-regulating proteins. As shown in Figure 3B,C, PA stimulated the expressions of pro-apoptotic protein Bax, Cyto c, and PARP, but reduced the expression of anti-apoptotic protein Bcl-2 compared with control $(p<0.01)$. Treatment with GLP for 12 and $24 \mathrm{~h}$ significantly prevented PA-induced cell apoptosis by upregulating Bcl-2 and downregulating Bax, Cyto $\mathrm{c}$, and PARP $(p<0.05$ or $p<0.01)$. Moreover, PA significantly increased caspase- 3 activation, which was verified by the cleavage of caspase- 3 and appearance of 17 and $19 \mathrm{kD}$ active fragments, whereas GLP suppressed caspase-3 activation at 6, 12, and $24 \mathrm{~h}(p<0.01)$. 
In PA-treated IPEC-J2 cells, the protein expressions of Cyto c, PARP, and caspase-3 activation were effectively inhibited by GLP exposure for $12 \mathrm{~h}$. However, after cells were incubated with GLP in the presence of PA for $24 \mathrm{~h}$, the rescuing effects of GLP on apoptosis-regulating proteins were weakened. Collectively, these findings validate that GLP can prevent PA-mediated apoptosis through the inhibition of mitochondrial pathway in IPEC-J2 cells.

\subsection{GLP Modulated PA-Induced Energy Metabolism in IPEC-J2 Cells}

To elucidate the effects of GLP on PA-induced mitochondrial energy metabolism, CS activity, ATP content, and the levels of AMPK and p-AMPK proteins were measured. CS is a validated biomarker for cellular mitochondrial content associated with mitochondrial function [13]. As shown in Figure 4A, CS activity in PA-induced cells was 55.61\% lower than that of control cells, whereas GLP $(0.4$ and $0.8 \mathrm{mg} / \mathrm{mL})$ greatly rescued PA-reduced CS activity $(p<0.01 ; n=5)$, suggesting that GLP can maintain cellular mitochondrial content and function in PA-induced cells. Change of mitochondrial ATP production plays a pivotal role in regulating apoptosis [14]. As shown in Figure 4B, PA-mediated cells exhibited a decrease of the level of ATP production $(p<0.01 ; n=5)$ compared with the control cells, whereas GLP treatment greatly restored the decreased ATP generation in PA-induced cells. To understand whether cellular ATP depletion affects the activation of AMPK, the protein levels of AMPK and p-AMPK were detected by Western blot analysis. As seen in Figure 4C, PA stimulation markedly increased the protein level of p-AMPK compared with control. In contrast, GLP exposure markedly prevented AMPK activation by suppressing the phosphorylation state of AMPK $(p<0.01 ; n=3)$. The phosphorylation of AMPK can be decreased at $12 \mathrm{~h}$ and increased with exposure time up to $24 \mathrm{~h}$ in cells incubated with PA in present of GLP.
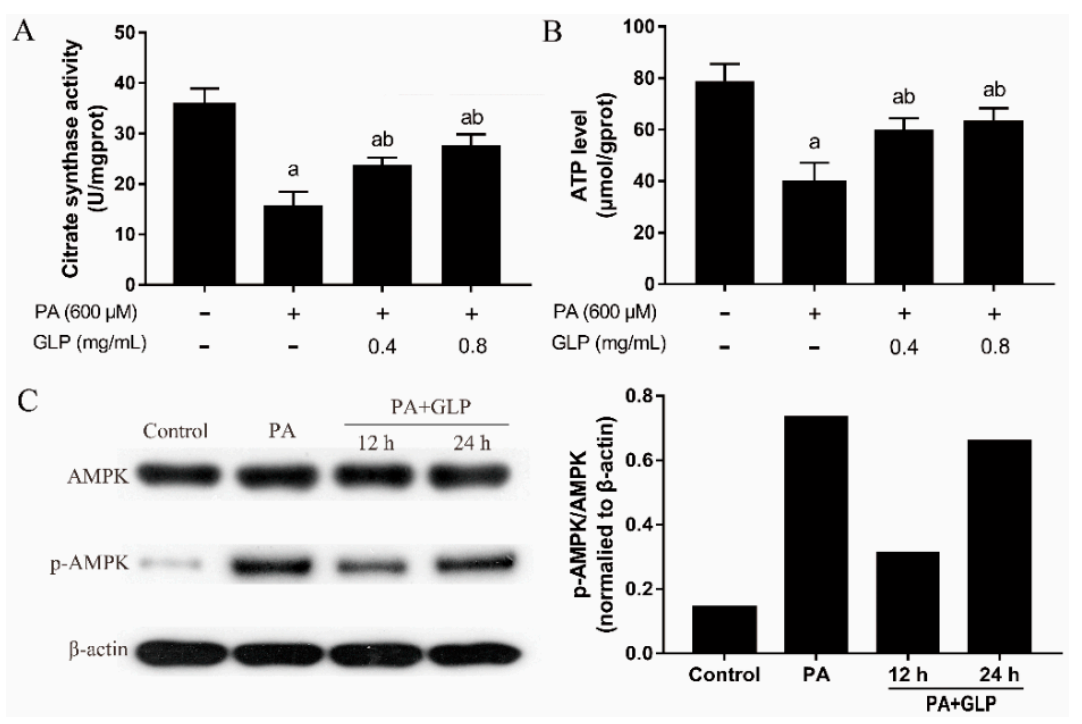

Figure 4. The effects GLP and PA on mitochondrial energy metabolism in IPEC-J2 cells. Cells were treated with $600 \mu \mathrm{M}$ PA or/and GLP $(0.4$ and $0.8 \mathrm{mg} / \mathrm{mL})$ for $24 \mathrm{~h}$. (A) Citrate synthase activity was assayed using a citrate synthase assay kit and expressed as $\mathrm{U} / \mathrm{mg}$ protein $(n=5)$. (B) Mitochondrial proteins were extracted using a mitochondria isolation kit after cells were lysed. The ATP level was determined by bioluminescence measurement and expressed as $\mu \mathrm{mol} / \mathrm{g}$ protein $(n=5)$.

(C) Representative Western blot of AMPK and p-AMPK. The data were quantified and normalized to $\beta$-actin. Data were presented as mean \pm SE for three independent experiments, a $<0.01$ vs. control, $\mathrm{b}<0.01$ vs. PA alone.

\subsection{GLP Inhibited PA-Induced Autophagy in IPEC-J2 Cells}

We assessed whether GLP protect PA-induced cell death was involved in the anti-autophagic effect through endogenous LC3 immunofluorescence. As shown in Figure 5A, green fluorescence was 
diffused in the cytoplasm and the immunoreactivity of LC3 was weak in control cells. Compared to control cells, punctuated structures with bright green fluorescence were gathered on the autophagy membrane in cells treated with $600 \mu \mathrm{M}$ PA for $24 \mathrm{~h}$, whereas punctuated structures significantly less in cells exposed to PA plus GLP, indicating that PA-caused autophagy was inhibited by GLP in IPEC-J2 cells. We then further examined three autophagy-related proteins, namely LC 3 , p62 and Beclin 1. As shown in Figure 5B, the induction of autophagy in PA-treated IPEC-J2 cells was confirmed by an increase in Beclin 1 and LC3-II expressions, as well as a decrease of p62 and LC3-I expressions. However, autophagy inhibition with GLP markedly up-regulated p62, down-regulated Beclin 1 and blocked LC3 conversion from LC3-I to LC3-II in presence of PA.
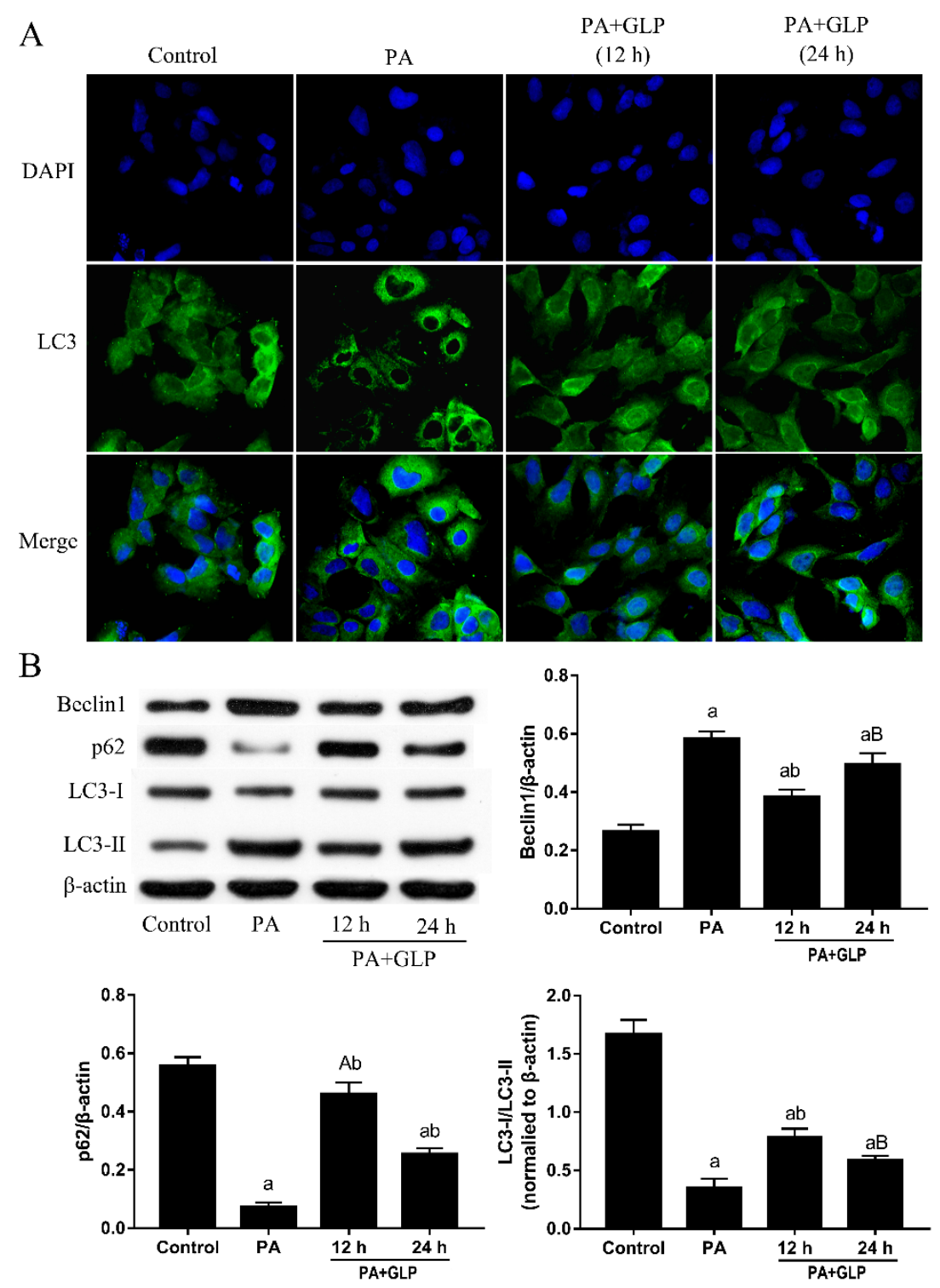

Figure 5. GLP ameliorated PA-induced autophagy in IPEC-J2 cells. Cells were treated with $600 \mu \mathrm{M}$ PA and GLP (0.4 and $0.8 \mathrm{mg} / \mathrm{mL}$ ) for $24 \mathrm{~h}$. (A) Representative LC3/DAPI images. Cells were stained for LC3 (green) and DAPI (blue), and the fluorescence was visualized in a fluorescence microscope. Original magnification $400 \times$. (B) The protein expressions of Beclin1, p62, LC3-I and LC3-II were subjected to Western blot analysis using indicating antibodies. The data were quantified and normalized to $\beta$-actin. Data shown are representative of three independent experiments $(n=3) . \mathrm{A}<0.05$ and $\mathrm{a}<0.01$ vs. control, $\mathrm{B}<0.05$ and $\mathrm{b}<0.01$ vs. PA alone. 


\subsection{GLP Decreased the Phosphorylation of MAPK Signaling Pathway in PA-Induced IPEC-J2 Cells}

To further determine the protective mechanism of GLP, total and phosphorylated MAPK pathway proteins were determined by Western blot. Results from Figure 6A,B showed that PA treatments resulted in significantly increased phosphorylation of JNK, p38, and ERK. Interestingly, we did not find any obvious influence on the expressions of JNK and p38 in any of treatment groups, although ERK, p-ERK, p-JNK, and p-p38 protein levels showed a significant change as compared with untreated cells. Compared with PA-untreated cells, GLP inhibited phosphorylation of MAPK signaling molecules, including p-ERK, p-JNK, and p-p38 with a maximum decrease at $12 \mathrm{~h}$, indicating that GLP alleviate PA-stimulated cell death through inactivating MAPK signal transduction pathway.

A
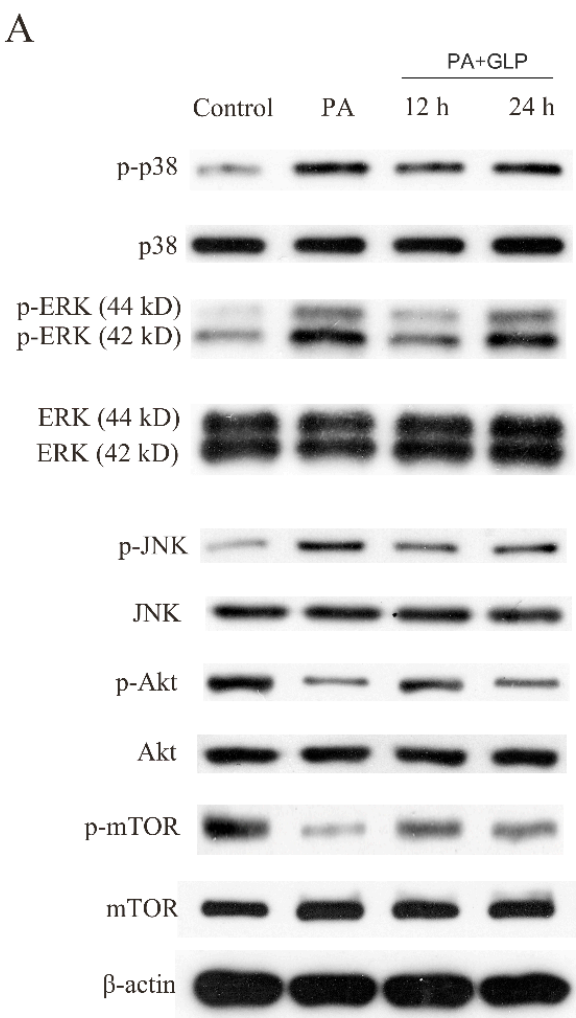

$\mathrm{C}$

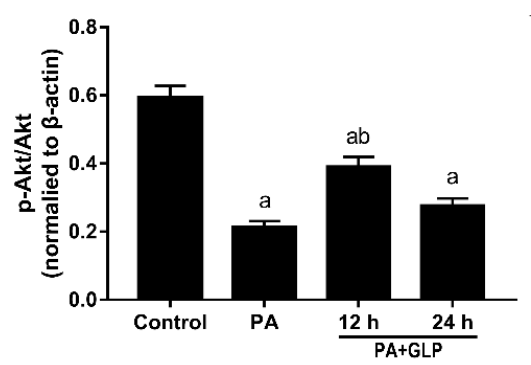

B
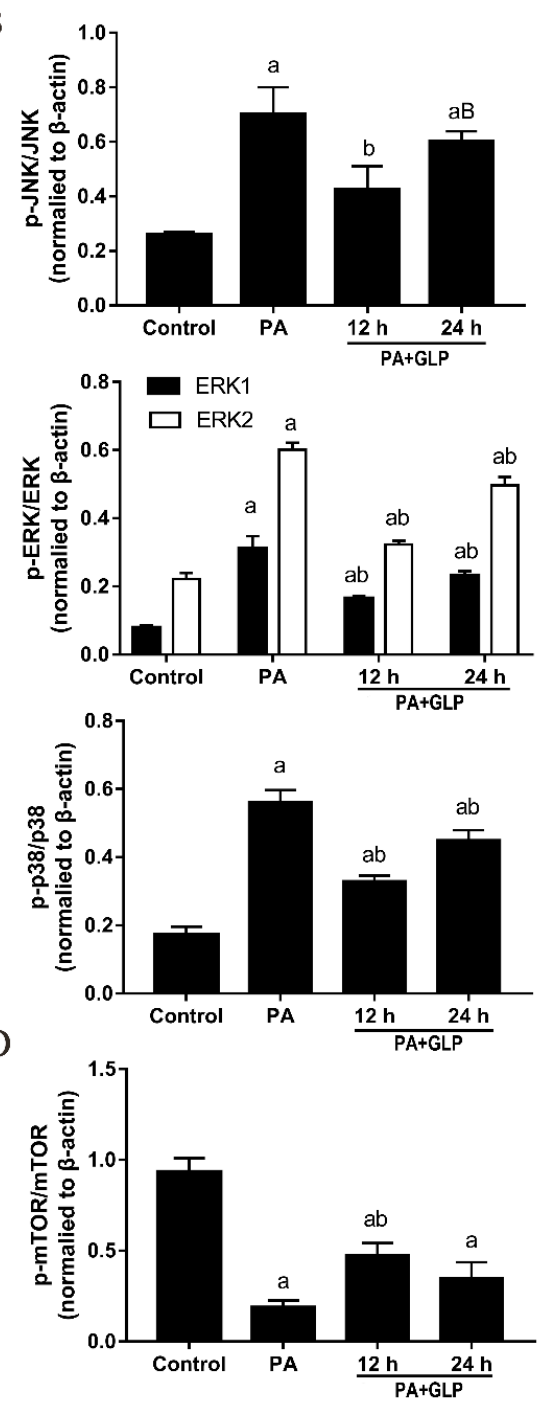

Figure 6. GLP activated Akt/mTOR signaling pathway and suppressed MAPK pathway in PA-induced IPEC-J2 cells. (A) Western blotting was used to analyze the protein expressions. (B) p-JNK/JNK, p-ERK/ERK, p-p38/p38, (C) p-Akt/Akt, and (D) p-mTOR/mTOR were calculated and presented. The data were quantified and normalized to $\beta$-actin. Data were presented as mean $\pm \mathrm{SE}$ for three independent experiments $(n=3), \mathrm{a}<0.01$ vs. control, $\mathrm{B}<0.05$ and $\mathrm{b}<0.01$ vs. PA alone.

\subsection{GLP Suppressed Akt/mTOR Pathway Inactivation Mediated by PA in IPEC-J2 Cells}

The Akt/mTOR signaling pathway is one of the most commonly altered pathways for regulating autophagy and apoptosis. Thus, we investigated whether this pathway is associated with PA-induced cell death, which also contributes to the protective effect of GLP. As shown in Figure 6A, PA decreased 
Akt and mTOR phosphorylation, whereas GLP partially increased Akt and mTOR phosphorylation without alteration in the expressions of Akt and mTOR. Additionally, compared with PA treatment, the ratios of $\mathrm{p}$-Akt/Akt and p-mTOR/mTOR were significantly enhanced by GLP at $12 \mathrm{~h}$ (Figure 6C,D, $p<0.01$ ), which was consistent with the peak of LC3-I/LC3-II ratio, indicating that Akt/mTOR signaling pathway may participate in the anti-autophagy and anti-apoptosis of GLP.

\section{Discussion}

Phytochemicals have been used in pharmaceutical and dietary therapy including polysaccharides, alkaloids, steroids, carotenoids, phenolic glycosides, flavonoids, and other nitrogen-containing compounds [15]. The search for phytochemicals without toxic side effects that can protect IECs from damage is a crucial way toward that development of effective treatment strategies for intestinal diseases before overt clinical symptoms develop. Both pigs and humans are omnivores consuming plant and animal ingredients, who organs generally share common functional features [16]. In terms of genetics, the size and the composition of the porcine genome are comparable to humans. Moreover, pigs are very similar to humans in terms of anatomy and physiology. Highlighting these similarities, pig-to-primate xenotransplantation are being used successfully [17]. Therefore, the porcine cell model has numerous advantages for disease research. In our previous study, we found oral administration of GLP (200 and $400 \mathrm{mg} / \mathrm{kg} \mathrm{bw}$ ) for 12 weeks significantly decreased body weight, lipid accumulation, and the tissue index of the liver, heart, and white adipose tissues in mice fed on a HFD [18]. In this study, we developed an IPEC-J2 cell model to investigate the potential protection of GLP on intestinal epithelial cell death induced by high-fat constituent. The results unveiled that excessive PA cause impairment of cell viability in IPEC-J2 cells. However, PA-induced cell viability loss was prevented by GLP without cytotoxicity, which coincided with previous findings showing that GLP was no toxicity to normal cells [19].

Apoptosis, a cellular process for control of cell survival and death, participates in various physiological activities including cardioprotection and embryogenesis [20,21]. In the gastrointestinal tract, apoptosis contributes to maintain an appropriate number of cells by balancing newly generated and dead cells and to modulate cell number migrating up the crypt-villus axis [22]. Nevertheless, extensive apoptosis in IECs leads to severe intestinal pathology resulting in rapid weight loss and animal death [23]. Of note, numerous evidence has confirmed that mitochondria drive apoptosis by regulating expression of $\mathrm{Bcl}-2$ family proteins, the release of Cyto $c$ from mitochondria to cytoplasm, and activation of caspase- 3 and PARP [24]. In accordance, we found that PA triggered a distinct apoptosis, which is connected to an increase of LDH release, caspase-3 cleavage, expressions of Bax, Cyto c, and PARP, as well as a decrease of Bcl-2 expression. However, GLP defended against PA-induced cell apoptosis via interruption of the mitochondrial apoptotic pathway.

Mitochondria are also the principal site for biochemical energy production, as ATP synthesis is produced from the inner surface of the mitochondrial inner membrane in higher organisms (yeast, plants, and mammals). CS localized in mitochondria are a key important limiting enzyme of tricarboxylic acid cycle, and its activity is inhibited by the level of the sum of the energy-rich phosphate bonds of ATP and ADP. On the contrary, data from a recent study reveal that CS can govern intracellular ATP synthesis. For example, RNAi-mediated CS knockdown in human cervical carcinoma cells impaired $\Delta \psi \mathrm{m}$, accelerated cytosolic glycolysis, and reduced ATP production [25]. AMPK is a key sensor of cellular energy status and regulates cellular metabolism to sustain energy homeostasis. Under conditions of low intracellular ATP, AMP binding stimulates AMPK by way of allosteric stimulation of phosphorylated AMPK and subsequently suppression of cell proliferation and biosynthetic processes and promotion of autophagy [26]. In the present study, PA exposure induced a decrease of ATP production and activation of AMPK, which may be partially responsive to the decreased CS activity, whereas GLP could effectively reverse the effect of PA on the energy metabolism. It was concluded that these critical alterations in mitochondrial energy metabolism contribute to the 
protective effect of GLP on mitochondrial function and biogenesis in PA-induced cells [27], a result similar to that presented by Dagon et al. [28].

Autophagy is a self-degradative cellular process that plays a wide variety of pathophysiological and physiological roles in removing intracellular pathogen, balancing sources of energy, eliminating abnormal aggregated proteins, clearing damaged and unwanted cells in normal multicellular organisms $[29,30]$. In mammalian cells, the cytoplasmic form LC3-I is processed and recruited to autophagosomes, and in turn lapidated to LC3-II by site-specific proteolysis, thereby inducing autophagy. The protein Beclin 1 is an essential mediator of autophagy, which BH3-like domain interacts with Bcl-2, and then regulates autophagosome formation and autophagy [31]. The major cargo receptor p62 affects the protein interaction between Bcl-2 and Beclin 1 through association with Bcl-2 and directly binds to the two autophagy effectors LC3-I and LC3-II during the autophagy process [32]. As reported, p62 aggregation in autophagy-deficient mice suggests a negative link between autophagy and p62, which could promote caspase-activated apoptosis [33]. It is noteworthy that AMPK triggers FoxO3a transcription factor activation, resulting in upregulation of the autophagy-associated proteins Beclin 1 and LC3-II in Tibialis anterior muscle and in primary mouse skeletal muscle myotubes [34]. In this study, the remarkably inhibitory effect of GLP on AMPK activation in PA-stimulated IPEC-J2 cells observed led us to think about whether these beneficial effects of GLP could be related to autophagy suppression. To investigate this possibility, autophagosomes were assessed using DAPI/LC3 staining and autophagy-related protein expressions were measured by Western blot analysis. The results provide support for the hypothesis that GLP exposure dampens PA-evoked autophagy in IPEC-J2 cells by the promotion of p62 expression level and reduction of autophagosome number, Beclin 1 protein expression and LC3-II/LC3-I conversion, which may be another important metabolic mechanism associated with the protection of GLP against IPEC-J2 cell death induced by PA.

MAPKs including JNK, p38, and ERK play vital roles in regulating cell growth, differentiation, migration, senescence, and the process of apoptosis and autophagy [35]. Both JNK and p38 MAPKs synchronously stimulated by a variety of endogenous and exogenous stresses adjusted the balance of cell apoptosis and autophagy [36]. The activation of JNK and p38 triggers autophagy as a pro-survival mechanism for cells to against the apoptotic and cytotoxic effects [37]. ERK is a survival factor in a central position for the cellular decision, the function of which has been depicted as growth stimuli, in essence by combating the upregulation of pro-apoptotic genes activated by JNK/p38 MAPK pathways [38]. However, recent reports have observed contrary results correlated with previous findings on the role of ERK pathway in cell survival. Kim et al. has reported that salinomycin-induced apoptosis was associated with ROS-mediated autophagy in human prostate cancer cells through regulation of ERK/p38 MAPK signaling pathway, and the reaction was suppressed by pretreatment with an ERK inhibitor [39]. This study indicated that GLP treatment effectively alleviated PA-mediated enhancement of $\mathrm{p} 38$, JNK, and ERK phosphorylation. The inhibition of MAPK pathway activation may contribute to suppressing PA-induced apoptosis and autophagy in IPEC-J2 cells. The results are similar to the conclusion in the studies of Liu et al. and Wei et al. In H9c2 cardiomyoblast cells, PA was reported to induce cell autophagy and apoptosis by stimulating p38 and JNK MAPK pathways as well as promoting the conversion of LC3-I to LC3-II [40]. ERK1/2 inhibitor, U0126, reduced the activated ERK and PA-induced apoptosis in rat cardiac muscle H9c2 cells through partial inhibition of intracellular ROS production [41].

Akt activation induces cell cycle progression, migration, and metabolism, whose downstream target mTOR is well-known as an essential regulator of protein synthesis, cell growth, and proliferation in mammalian cells [42]. In particular, dysregulation of mTOR signaling contributes to cell autophagy and apoptosis by modulating various signal molecules, such as inhibition of Akt activity and promotion of AMPK [43]. Constitutive activation of the Akt/mTOR pathway increases cell survival and meanwhile prevents apoptosis and autophagy in an uncontrolled manner [44]. In this study, exposure of PA obviously decreased the Akt and mTOR phosphorylation levels in IPEC-J2 cells. However, GLP rescued PA-medicated reduction in $\mathrm{p}-\mathrm{Akt} / \mathrm{Akt}$ ratio and $\mathrm{p}-\mathrm{mTOR} / \mathrm{mTOR}$ ratio. Thus, another 
novel finding of our present study is that GLP can prevent IPEC-J2 cells from PA-induced cell death via modulation of Akt/mTOR pathway. Interestingly, some reports found that induction of Akt and mTOR expressions can regulate Bcl-2 phosphorylation. Suppression of mTOR signaling by the expression of a dominant negative mutant of the Akt kinase cause an increase in Bcl-2 phosphorylation in HEK23 human embryonic kidney cells [45], suggesting that Akt inactivation may inhibit mTOR expression and upregulate Bcl-2 phosphorylation, thereby preventing cell apoptosis. Nevertheless, different results were obtained in this study, that is, GLP suppressed cell autophagy and apoptosis caused by PA via inactivation of Akt/mTOR signaling pathway and accompanied by inhibition of Bcl-2 phosphorylation in IPEC-J2 cells.

Results from the expression of target proteins including Cyto c, PARP, caspase-3, p-AMPK, Beclin 1, p62, LC3-I, LC3-II, p-p38, p-JNK, p-ERK, p-AKt, and p-mTOR in apoptotic and autophagic processes show that GLP displayed effectively anti-apoptotic and anti-autophagic effects at incubation $12 \mathrm{~h}$ in PA-incubated IPEC-J2 cells, whereas the strength of the rescuing effects of GLP were weakened at incubation $24 \mathrm{~h}$, but still significant. The trend of results was similar with previous work those of Pan et al., whom reported that $100 \mu \mathrm{M}$ Cordycepin induced cleavage of caspase- $-3,-6,-7,-8$, and PARP with maximal cleavage at $12 \mathrm{~h}$ in mouse Leydig tumor cells [46]. Most drugs enter cells through diffusion or endocytosis, then are absorbed and metabolized in a variable fashion. Accordingly, the concentration of drugs becomes decreased in conditioned media of cells, and the drug effect gradually diminish. This may be the reason that the rescuing effects of GLP was progressively lost with the extension of incubation time.

\section{Materials and Methods}

\subsection{Preparation of $G L P$}

GLP were isolated from the fruit bodies of Ganoderma lucidum as described by Liang et al. [47]. Structural characteristics of the extract were investigated using UV spectra, infrared spectra, and high-performance anion exchange chromatography (HPAEC). These findings suggested that the extract was composed of acidic polysaccharides containing $11 \%$ uronic acid and $89 \%$ total carbohydrate. GLP were mainly comprised of cellose, glucose, galactose, and arabinose in the mole percentages of $5.56 \%, 16.67 \%, 16.67 \%$, and $61.11 \%$ with $\alpha$-type glycosidic linkage. The molecular weight range were $10-30 \mathrm{kDa}(32.1 \%), 30-50 \mathrm{kDa}(21.8 \%)$, and $>50 \mathrm{kDa}(46.1 \%)$, respectively. Freeze-dried GLP powder was dissolved in RPMI 1640 media with 10\% fetal bovine serum (FBS), filter sterilized, and stored at $-20{ }^{\circ} \mathrm{C}$ for later analysis.

\subsection{Cell Line and Culture}

IPEC-J2 cell line isolated from a neonatal, unsuckled piglet and immortalized with the human telomerase reverse transcriptase (hTERT) gene [48,49] was obtained from Hunan Agricultural University. Cells were maintained in 1640 medium with $10 \%$ FBS at $37{ }^{\circ} \mathrm{C}$ under a humidified atmosphere containing 5\% CO2. PA (Sigma, St. Louis, MO, USA) was dissolved in $100 \%$ ethanol at $200 \mathrm{mM}$ and then diluted in 1640 medium containing 10\% fatty acid-free bovine serum albumin (BSA, Sigma, St. Louis, MO, USA) to a concentration of $50 \mathrm{mM}$. The final concentration of ethanol in all experiments was lower than $0.5 \% v / v$ in cell culture media. The stock solutions were adjusted to $\mathrm{pH} 7.4$, filtered through $0.22 \mu \mathrm{m}$ filter membranes, and stored in refrigerator until ready for use.

\subsection{Assessment of Cell Viability by MTT}

Cells $\left(1 \times 10^{5}\right.$ cells $\left./ \mathrm{mL}\right)$ were seeded in 96-well plates for $24 \mathrm{~h}$ and then treated with various concentrations of PA or/and GLP for $24 \mathrm{~h}$. At the end of the treatment, cell viability was determined at $490 \mathrm{~nm}$ by an ELISA reader (Thermo Multiskan MK3, Waltham, MA, USA) using the colorimetric 3-(4,5-Dimethylthiazol-2-yl)-2,5-diphenyltetrazolium bromide (MTT, Beyotime Biochemical Co., Shanghai, China) according to the manufacturer's instructions as described 
previously [50]. Cell viability (\%) was calculated as [(sample OD value-reference OD value)/control OD value] $\times 100 \%$. All the samples were conducted in five replicates.

\subsection{DAPI Staining}

After cells $\left(2 \times 10^{5}\right.$ cells $\left./ \mathrm{mL}\right)$ were incubated with $600 \mu \mathrm{M}$ PA or/and GLP $(0.4$ and $0.8 \mathrm{mg} / \mathrm{mL})$ for $24 \mathrm{~h}$, nuclear morphology was analyzed by DAPI staining. In brief, treated cells were centrifuged, washed with phosphate buffer saline (PBS, pH7.4) one time, and fixed in $4 \%$ paraformaldehyde for $0.5 \mathrm{~h}$ at room temperature. The samples were washed in PBS three times for $10 \mathrm{~min}$ each before staining with $1 \mu \mathrm{g} / \mathrm{mL}$ of DAPI (Sigma, St. Louis, MO, USA) in the dark at $37^{\circ} \mathrm{C}$ for $30 \mathrm{~min}$. Subsequently, each sample was washed with PBS six times to remove unbound DAPI and observed under a fluorescence inverted microscope (Olympus, CKX41SF, Tokyo, Japan).

\subsection{Detection of Mitochondrial Membrane Potential}

The mitochondrial membrane potential $(\Delta \psi \mathrm{m})$ was examined with a $\Delta \psi \mathrm{m}$-dependent lipophilic dye JC-1. 5,5',6,6'-tetrachloro-1,1',3,3'-tetraethylbenzimidazolylcarbocyanine iodide (JC-1, St. Louis, MO, USA) were dissolved in dimethyl sulfoxide (DMSO, St. Louis, MO, USA) and diluted in 1640 medium supplemented with 10\% FBS. After treatment, cells were incubated with $1 \mathrm{~mL}$ of $5 \mu \mathrm{M} \mathrm{JC}-1$ or CCCP (Sigma, St. Louis, MO, USA) for $20 \mathrm{~min}$ at $37^{\circ} \mathrm{C}$ in the dark, washed with ice-cold PBS and added cellular medium. Finally, JC-1 aggregate and JC-1 monomer fluorescence was analyzed using an inverted fluorescence microscope (Olympus, CKX41SF, Tokyo, Japan) and a multifunctional microplate reader (TECAN, Infinite 200 PRO, Grodig, Austria) by excitation/emission at $525 \mathrm{~nm} / 590 \mathrm{~nm}$ (red fluorescence) and $490 \mathrm{~nm} / 530 \mathrm{~nm}$ (green fluorescence) wavelength, respectively. The mitochondrial potential disrupter CCCP was used as a positive control.

\subsection{Cell Membrane Integrity Assay}

IPEC-J2 cells $\left(2 \times 10^{5}\right.$ cells $\left./ \mathrm{mL}\right)$ were seeded in 96-well plates overnight followed by incubation with GLP $(0.4$ and $0.6 \mathrm{mg} / \mathrm{mL})$ or/and $600 \mu \mathrm{M}$ PA for $24 \mathrm{~h}$. At the end of the incubation period, cells were centrifuged at $3000 \times g$ for $10 \mathrm{~min}$, and then the cultured supernatant was transferred to new 96-well plates. To measure cell membrane integrity, LDH release was detected at $450 \mathrm{~nm}$ by a microplate reader (Molecular Devices, Sunnyvale, CA, USA) using a Lactate dehydrogenase (LDH) assay kit (Nanjing Jiancheng Bioengineering Institute, China).

\subsection{Apoptosis}

Cells $\left(2 \times 10^{5}\right.$ cells $\left./ \mathrm{mL}\right)$ were exposed to $600 \mu \mathrm{M}$ PA with or without GLP $(0.4$ and $0.8 \mathrm{mg} / \mathrm{mL})$ for $24 \mathrm{~h}$. After washed twice with pre-chilled 0.01 M PBS ( $\mathrm{pH} 7.4$ ), cells were suspended in $500 \mu \mathrm{L} 1 \times$ binding buffer prior to exposure to $5 \mu \mathrm{L}$ of Annexin V- Fluorescein isothyocyanate (FITC, BD Biosciences, San Jose, CA, USA) and $5 \mu \mathrm{L}$ of propidium iodide (PI) for $15 \mathrm{~min}$ at room temperature in the dark. Cell apoptosis was monitored by flow cytometry (Beckman Coulter, Inc., Miami, FL, USA) within $1 \mathrm{~h}$.

\subsection{Citrate Synthase Activity Assay}

Citrate synthase enzyme assay was performed spectrophotometrically using a citrate synthase assay kit (Nanjing Jiancheng Bioengineering Institute, China). After treatment, cells were lysed with ice-cold RIPA buffer $(150 \mathrm{mmol} \mathrm{NaCl}, 0.1 \%$ Triton X-100, 0.5\% sodium deoxycholate, $50 \mathrm{mmol}$ Tris- $\mathrm{HCl}, \mathrm{pH} 8.0$ ), and the total protein concentrations were determined using a BCA kit (Beyotime Biochemical Co., Shanghai, China). The cell lysate was added with a reaction mixture consisting of $5 \mathrm{mM}$ triethanolamine hydrochloride, $100 \mathrm{mM}$ Tris- $\mathrm{HCl}$ ( $\mathrm{pH} 8.0), 30 \mathrm{mM}$ acetyl-CoA, 1 M EDTA, $10 \mathrm{mM}$ 5,5'-dithiobis-(2-nitrobenzoic acid) (DTNB) and $10 \mathrm{mM}$ oxaloacetate (OAA). The absorption was measured spectrophotometrically at $412 \mathrm{~nm}$ at $25^{\circ} \mathrm{C}$ and expressed as $\mathrm{U} / \mathrm{mg}$ protein. 


\subsection{Determination of the Level of Mitochondrial ATP}

IPEC-J2 cells $\left(2 \times 10^{5}\right.$ cells $\left./ \mathrm{mL}\right)$ were incubated $600 \mu \mathrm{M}$ PA or/and GLP $(0.4$ and $0.8 \mathrm{mg} / \mathrm{mL})$ for $24 \mathrm{~h}$. After cells were lysed with ice-cold RIPA buffer, mitochondrial proteins were extracted using a mitochondria isolation kit. Subsequently, protein concentrations were determined using a BCA protein assay kit. The mitochondrial ATP level was quantified using an ATP assay kit (Nanjing Jiancheng Bioengineering Institute, China) according to the manufacturer's instructions, determined by bioluminescence measurement using a UV-Vis Shimadzu UV-1800 spectrophotometer (Shimadzu Corporation, Kyoto, Japan) at $560 \mathrm{~nm}$ and expressed as $\mu \mathrm{mol} / \mathrm{g}$ protein.

\subsection{Immunofluorescence}

Cells $\left(2 \times 10^{5}\right.$ cells $\left./ \mathrm{mL}\right)$ were exposed to $600 \mu \mathrm{M}$ PA with or without GLP $(0.4$ and $0.8 \mathrm{mg} / \mathrm{mL})$ for $24 \mathrm{~h}$. Treated and untreated cells were fixed by $4 \%$ paraformaldehyde, permeabilized with $0.3 \%$ Triton X-100 and blocked with 5\% BSA in PBS. Subsequently, the samples were incubated with LC3B antibody (1:100) overnight at $4{ }^{\circ} \mathrm{C}$. Following washes with PBS, the coverslips were incubated with $150 \mu \mathrm{L}$ Alexa Fluor 488-conjugated donkey anti-rabbit IgG $(\mathrm{H}+\mathrm{L})$ for $1.5 \mathrm{~h}$ at $37^{\circ} \mathrm{C}$. Cell nuclei were counterstained with DAPI. Fluorescent images were examined using a fluorescence microscope (Olympus, CKX41SF, Tokyo, Japan).

\subsection{Western Blot Analysis}

IPEC-J2 cells $\left(2 \times 10^{5}\right.$ cells $\left./ \mathrm{mL}\right)$ were seeded in six-well plates with $600 \mu \mathrm{M}$ PA and different concentrations of GLP at corresponding time, and then total protein were extracted from IPEC-J2 cell pellet. Protein concentration was estimated using BCA assay and stored at $-80^{\circ} \mathrm{C}$ until analysis. Twenty microgram total protein were diluted in loading buffer, separated on $10 \%$ and $12 \%$ sodium dodecyl sulphate-polyacrylamide (SDS-PAGE) gels electrophoresis and transferred onto polyvinylidene fluoride (PVDF) membranes. The blots were blocked in Tris-buffered saline containing 0.1\% Tween 20 (TBST) supplemented with $5 \% \mathrm{BSA}$, and then probed with the primary antibodies at $4{ }^{\circ} \mathrm{C}$ overnight. After three washes with TBST, the membranes were probed with HRP secondary antibodies (Proteintech, Chicago, IL, USA) at room temperature for $1 \mathrm{~h}$. $\beta$-actin served as an internal control. The specific proteins were visualized using an enhanced chemiluminescence detection kit according to the manufacturer's instructions. Densitometry was performed using ImageJ software (v.1.8).

\subsection{Statistical Analysis}

Results are presented as means \pm standard error (SE). Statistical analysis was performed with Statistical Program for Social Sciences v.18.0 (SPSS Inc., Chicago, IL, USA) software. Multiple comparisons were made using an analysis of variance (ANOVA) for repeated measures followed by Tukey's post hoc test. A significant difference was considered as $p<0.05$ and an extremely significant difference was expressed as $p<0.01$.

\section{Conclusions}

In summary, our study provides the first evidence that GLP could reverse PA-induced cytotoxicity by concomitantly inhibiting apoptosis and autophagy in IPEC-J2 cells without cytotoxicity. GLP effectively suppressed apoptosis and autophagy via restoration of mitochondrial function, inactivation of the mitochondrial, MAPK, and Akt/mTOR signaling pathways. Further studies are required to determine the precise mechanisms of cell death, as well as the interaction between signaling pathways related to apoptosis and autophagy in vitro.

Author Contributions: Z.L. and Y.S. designed the research; Z.L., J.G., Z.Y., J.D. and Y.S. carried out the experiments and performed the statistical analysis; Z.L., J.G. and Z.Y. analyzed and interpreted the data; Z.L., J.W. and J.Y. wrote the paper; and Z.Y., J.W., J.Y. and Y.S. revised the manuscript critically for important intellectual content. All authors read and approved the final version of this manuscript. 
Funding: This work was supported by the National Natural Science Foundation of China (grant number 31501484), Hunan Provincial Natural Science Foundation of China (grant number 2016JJ3081) and Hunan Agricultural Science and Technology Innovation Team Project (grant numbers 2017GC03, 2018QN27 and 2018ZD04).

Conflicts of Interest: The authors declare no conflict of interest. The funders had no role in the design of the study; in the collection, analyses, or interpretation of data; in the writing of the manuscript, or in the decision to publish the results.

\section{References}

1. Moreira, A.P.B.; Texeira, T.F.S.; Ferreira, A.B.; Peluzio, M.C.G.; Alfenas, R.C.G. Influence of a high-fat diet on gut microbiota, intestinal permeability and metabolic endotoxaemia. Br. J. Nutr. 2012, 108, 801-809. [CrossRef] [PubMed]

2. Akbari, P.; Fink-Gremmels, J.; Willems, R.H.A.M.; Difilippo, E.; Schols, M.H.C.; Garssen, J.; Braber, S. Characterizing microbiota-independent effects of oligosaccharides on intestinal epithelial cells: Insight into the role of structure and size. Eur. J. Nutr. 2017, 56, 1919-1930. [CrossRef]

3. Nguyen, H.T.T.; Dalmasso, G.; Müller, S.; Carrière, J.; Seibold, F.; Darfeuille-Michaud, A. Crohn's disease-associated adherent invasive escherichia coli modulate levels of microRNAs in intestinal epithelial cells to reduce autophagy. Gastroenterology 2014, 146, 508-519. [CrossRef] [PubMed]

4. Peterson, L.W.; Artis, D. Intestinal epithelial cells: Regulators of barrier function and immune homeostasis. Nat. Rev. Immunol. 2014, 14, 141-153. [CrossRef] [PubMed]

5. Elkahoui, S.; Bartley, G.E.; Yokoyama, W.H.; Friedman, M. Dietary supplementation of potato peel powders prepared from conventional and organic russet and non-organic gold and red potatoes reduces weight gain in mice on a high-fat diet. J. Agric. Food Chem. 2018, 66, 6064-6072. [CrossRef] [PubMed]

6. Thomas, M.; Kim, S.; Guo, W.M.; Collins, F.W.; Wise, M.L.; Meydani, M. High levels of avenanthramides in oat-based diet further suppress high fat diet-induced atherosclerosis in Ldlr-/- mice. J. Agric. Food Chem. 2018, 66, 498-504. [CrossRef]

7. Risio, M.; Lipkin, M.; Newmark, H.; Yang, K.; Rossini, F.P.; Steele, V.E.; Boone, C.W.; Kelloff, G.J. Apoptosis, cell replication, and western-style diet-induced tumorigenesis in mouse colon. Cancer Res. 1996, 56, $4910-4916$.

8. Luo, J.M.; Zhang, C.; Liu, R.; Gao, L.J.; Ou, S.Y.; Liu, L.; Peng, X.C. Ganoderma lucidum polysaccharide alleviating colorectal cancer by alteration of special gut bacteria and regulation of gene expression of colonic epithelial cells. J. Funct. Foods 2018, 47, 127-135. [CrossRef]

9. Sun, X.Z.; Liao, Y.; Li, W.; Guo, L. Neuroprotective effects of Ganoderma lucidum polysaccharides against oxidative stress-induced neuronal apoptosis and antimicrobial activities. Neural Regen. Res. 2017, 12, 953-958.

10. Xiao, C.; Wu, Q.; Zhang, J.; Xie, Y.Z.; Cai, W.; Tan, J.B. Antidiabetic activity of Ganoderma lucidum polysaccharides F31 downregulated hepatic glucose regulatory enzymes in diabetic mice. J. Ethnopharmacol. 2017, 196, 47-57. [CrossRef]

11. Xiao, C.; Wu, Q.P.; Cai, W.; Tan, J.B.; Yang, X.B.; Zhang, J.M. Hypoglycemic effects of Ganoderma lucidum polysaccharides in type 2 diabetic mice. Arch. Pharm. Res. 2012, 35, 1793-1801. [CrossRef] [PubMed]

12. Li, X.; Gorle, A.K.; Ainsworth, T.D.; Heimann, K.; Collins, J.G.; Keene, F.R. RNA and DNA binding of inert oligonuclear ruthenium (II) complexes in live eukaryotic cells. Dalton Trans. 2015, 44, 3594-3603. [CrossRef] [PubMed]

13. Jaenisch, R.B.; Bertagnolli, M.; Borghi-Silva, A.; Arena, R.; Lago, P.D. Respiratory muscle training improves diaphragm citrate synthase activity and hemodynamic function in rats with heart failure. Braz. J. Cardiovasc. Surg. 2017, 32, 104-110. [CrossRef] [PubMed]

14. Mukhopadhyay, S.; Das, D.N.; Panda, P.K.; Sinha, N.; Naik, P.P.; Bissoyi, A.; Pramanik, K.; Bhutia, S.K. Autophagy protein Ulk1 promotes mitochondrial apoptosis through reactive oxygen species. Free Radic. Biol. Med. 2015, 89, 311-321. [CrossRef] [PubMed]

15. Trabelsi, L.; Mnari, A.; Abdel-Daim, M.M.; Abid-Essafi, S.; Aleya, L. Therapeutic properties in Tunisian hot springs: First evidence of phenolic compounds in the cyanobacterium Leptolyngbya sp. biomass, capsular polysaccharides and releasing polysaccharides. BMC Complement. Altern. Med. 2016, 16, 515. [CrossRef] [PubMed]

16. Meurens, F.; Summerfield, A.; Nauwynck, H.; Saif, L.; Gerdts, V. The pig: A model for human infectious diseases. Trends Microbiol. 2012, 20, 50-57. [CrossRef] [PubMed] 
17. Cooper, D.K.C.; Ezzelarab, M.B.; Hara, H.; Iwase, H.; Lee, W.; Wijkstrom, M.; Bottino, R. The pathobiology of pig-to-primate xenotransplantation: A historical review. Xenotransplantation 2016, 23, 83-105. [CrossRef] [PubMed]

18. Liang, Z.; Yuan, Z.H.; Li, G.Y.; Fu, F.H.; Shan, Y. Hypolipidemic, antioxidant, and antiapoptotic effects of polysaccharides extracted from reishi mushroom, Ganoderma lucidum (Leyss: Fr) Karst, in mice fed a high-fat die. J. Med. Food 2018. [CrossRef]

19. Zhang, J.J.; Gao, X.; Pan, Y.G.; Xu, N.; Le, J. Toxicology and immunology of Ganoderma lucidum polysaccharides in Kunming mice and Wistar rats. Int. J. Biol. Macromol. 2016, 85, 302-310. [CrossRef]

20. Wang, J.; Aung, L.H.H.; Prabhakar, B.S.; Li, P. The mitochondrial ubiquitin ligase plays an anti-apoptotic role in cardiomyocytes by regulating mitochondrial fission. J. Cell. Mol. Med. 2016, 20, 2278-2288. [CrossRef]

21. Ke, F.F.S.; Vanyai, H.K.; Cowan, A.D.; Delbridge, A.R.D.; Whitehead, L.; Grabow, S.; Czabotar, P.E.; Voss, A.K.; Strasser, A. Embryogenesis and adult life in the absence of intrinsic apoptosis effectors BAX, BAK, and BOK. Cell 2018, 173, 1217-1230. [CrossRef] [PubMed]

22. Watson, A.J. Necrosis and apoptosis in the gastrointestinal tract. Gut 1995, 37, 165-167. [CrossRef]

23. Dannappel, M.; Vlantis, K.; Kumari, S.; Polykratis, A.; Kim, C.; Wachsmuth, L.; Eftychi, C.; Lin, J.; Corona, T.; Hermance, N.; et al. RIPK1 maintains epithelial homeostasis by inhibiting apoptosis and necroptosis. Nature 2014, 513, 90-94. [CrossRef] [PubMed]

24. Schüll, S.; Günther, S.D.; Brodesser, S.; Seeger, J.M.; Tosetti, B.; Wiegmann, K.; Pongratz, C.; Diaz, F.; Witt, A.; Andree, M.; et al. Cytochrome c oxidase deficiency accelerates mitochondrial apoptosis by activating ceramide synthase 6. Cell Death Dis. 2015, 6, e1691. [CrossRef] [PubMed]

25. Lin, C.C.; Cheng, T.L.; Tsai, W.H.; Tsai, H.J.; Hu, K.H.; Chang, H.C.; Yeh, C.W.; Chen, Y.C.; Liao, C.C.; Chang, W.T. Loss of the respiratory enzyme citrate synthase directly links the Warburg effect to tumor malignancy. Sci. Rep. 2012, 2, 785. [CrossRef]

26. Cai, Q.X.; Zhao, M.M.; Liu, X.; Wang, X.C.; Nie, Y.; Li, P.; Liu, T.; Ge, R.; Han, F.C. Reduced expression of citrate synthase leads to excessive superoxide formation and cell apoptosis. Biochem. Biophys. Res. Commun. 2017, 485, 388-394. [CrossRef]

27. Jaiswal, N.; Maurya, C.K.; Arha, D.; Avisetti, D.R.; Prathapan, A.; Raj, P.S.; Raghu, K.G.; Kalivendi, S.V.; Tamrakar, A.K. Fructose induces mitochondrial dysfunction and triggers apoptosis in skeletal muscle cells by provoking oxidative stress. Apoptosis 2015, 20, 930-947. [CrossRef]

28. Dagon, Y.; Avraham, Y.; Berry, E.M. AMPK activation regulates apoptosis, adipogenesis, and lipolysis by eIF2 $\alpha$ in adipocytes. Biochem. Biophys. Res. Commun. 2006, 340, 43-47. [CrossRef]

29. D'Assantea, R.; Fuscoa, A.; Palamaro, L.; Polishchuk, E.; Polishchuk, R.; Bianchino, G.; Grieco, V.; Prencipe, M.R.; Ballabio, A.; Pignata, C. Abnormal cell-clearance and accumulation of autophagic vesicles in lymphocytes from patients affected with Ataxia-Teleangiectasia. Clin. Immunol. 2017, 175, 16-25. [CrossRef]

30. Jiang, P.; Mizushima, N. LC3- and p62-based biochemical methods for the analysis of autophagy progression in mammalian cells. Methods 2015, 75, 13-18. [CrossRef]

31. Fernández, F.; Sebti, S.; Wei, Y.; Zou, Z.; Shi, M.; McMillan, K.L.; Schiattarella, G.G.; Bhagat, G.; Moe, O.W.; $\mathrm{Hu}$, M.C.; et al. Disruption of the beclin 1-BCL2 autophagy regulatory complex promotes longevity in mice. Nature 2018, 561, 136-140. [CrossRef]

32. Zhou, L.; Wang, H.F.; Ren, H.G.; Chen, D.; Gao, F.; Hu, Q.S.; Fu, C.; Xu, R.J.; Ying, Z.; Wang, G.H. Bcl-2-dependent upregulation of autophagy by sequestosome 1/p62 in vitro. Acta Pharmacol. Sin. 2013, 34, 651-656. [CrossRef]

33. Komatsu, M.; Waguri, S.; Koike, M.; Sou, Y.S.; Ueno, T.; Hara, T.; Mizushima, T.; Iwata, J.; Ezaki, J.; Murata, J.; et al. Homeostatic levels of p62 control cytoplasmic inclusion body formation in autophagy-deficient mice. Cell 2007, 131, 1149-1163. [CrossRef] [PubMed]

34. Sanchez, A.M.J.; Csibi, A.; Raibon, A.; Cornille, K.; Gay, S.; Bernardi, H.; Candau, R. AMPK promotes skeletal muscle autophagy through activation of forkhead FoxO3a and interaction with Ulk1. J. Cell. Biochem. 2012, 113, 695-710. [CrossRef] [PubMed]

35. Kim, E.K.; Choi, E.J. Compromised MAPK signaling in human diseases: An update. Arch. Toxicol. 2015, 89, 867-882. [CrossRef]

36. Sui, X.B.; Kong, N.; Ye, L.; Han, W.D.; Zhou, J.C.; Zhang, Q.; He, C.; Pan, H.M. p38 and JNK MAPK pathways control the balance of apoptosis and autophagy in response to chemotherapeutic agents. Cancer Lett. 2014, 344, 174-179. [CrossRef] 
37. Shen, Y.; Yang, J.J.; Zhao, J.; Xiao, C.J.; Xu, C.M.; Xiang, Y. The switch from ER stress-induced apoptosis to autophagy via ROS-mediated JNK/p62 signals: A survival mechanism in methotrexate-resistant choriocarcinoma cells. Exp. Cell Res. 2015, 334, 207-218. [CrossRef] [PubMed]

38. Junttila, M.R.; Li, S.P.; Westermarck, J. Phosphatase-mediated crosstalk between MAPK signaling pathways in the regulation of cell survival. FASEB J. 2007, 22, 954-965. [CrossRef]

39. Kim, K.Y.; Park, K.; Kim, S.H.; Yu, S.N.; Park, S.G.; Kim, Y.W.; Seo, Y.K.; Ma, J.Y.; Ahn, S.C. Inhibition of autophagy promotes salinomycin-induced apoptosis via reactive oxygen species-mediated $\mathrm{PI} 3 \mathrm{~K} / \mathrm{AKT} / \mathrm{mTOR}$ and ERK/p38 MAPK-dependent signaling in human prostate cancer cells. Int. J. Mol. Sci. 2017, 18, 1088. [CrossRef]

40. Liu, J.; Chang, F.; Li, F.; Fu, H.; Wang, J.; Zhang, S.; Zhao, J.; Yin, D. Palmitate promotes autophagy and apoptosis through ROS-dependent JNK and p38 MAPK. Biochem. Biophys. Res. Commun. 2015, 463, 262-267. [CrossRef] [PubMed]

41. Wei, C.D.; Li, Y.; Zheng, H.Y.; Tong, Y.Q.; Dai, W. Palmitate induces H9c2 cell apoptosis by increasing reactive oxygen species generation and activation of the ERK1/2 signaling pathway. Mol. Med. Rep. 2013, 7, 855-861. [CrossRef] [PubMed]

42. Guo, P.; Wang, J.; Liu, J.; Xia, M.; Li, W.; He, M. Macrophage immigration inhibitory factor promotes cell proliferation and inhibits apoptosis of cervical adenocarcinoma. Tumor Biol. 2015, 36, 5095-5102. [CrossRef]

43. Xu, Y.; Liu, C.; Chen, S.; Ye, Y.; Guo, M.; Ren, Q.; Liu, L.; Zhang, H.; Xu, C.; Zhou, Q.; et al. Activation of AMPK and inactivation of Akt result in suppression of mTOR-mediated S6K1 and 4E-BP1 pathways leading to neuronal cell death in in vitro models of Parkinson's disease. Cell. Signal. 2014, 26, 1680-1689. [CrossRef] [PubMed]

44. Kumar, D.; Das, B.; Sen, R.; Kundu, P.; Manna, A.; Sarkar, A.; Chowdhury, C.; Chatterjee, M.; Das, P. Andrographolide analogue induces apoptosis and autophagy mediated cell death in U937 cells by inhibition of PI3K/Akt/mTOR pathway. PLoS ONE 2015, 10, e0139657. [CrossRef]

45. Asnaghi, L.; Calastretti, A.; Bevilacqua, A.; D'Agnano, I.; Gatti, G.; Canti, G.; Delia, D.; Capaccioli, S.; Nicolin, A. Bcl-2 phosphorylation and apoptosis activated by damaged microtubules require mTOR and are regulated by Akt. Oncogene 2004, 23, 5781-5791. [CrossRef]

46. Pan, B.S.; Wang, Y.K.; Lai, M.S.; Mu, Y.F.; Huang, B.M. Cordycepin induced MA-10 mouse Leydig tumor cell apoptosis by regulating p38 MAPKs and PI3K/AKT signaling pathways. Sci. Rep. 2015, 5, 13372. [CrossRef] [PubMed]

47. Liang, Z.; Yi, Y.J.; Guo, Y.T.; Wang, R.C.; Hu, Q.L.; Xiong, X.Y. Chemical characterization and antitumor activities of polysaccharide extracted from Ganoderma lucidum. Int. J. Mol. Sci. 2014, 15, 9103-9116. [CrossRef] [PubMed]

48. Zhao, D.; Li, Q.; Huang, Q.; Li, X.; Yin, M.; Wang, Z.; Hong, J. Cardioprotective effect of propofol against oxygen glucose deprivation and reperfusion injury in H9c2 cells. Oxidative Med. Cell. Longev. 2017, 2015, 184938.

49. Rhoads, J.M.; Chen, W.; Chu, P.; Berschneider, H.M.; Argenzio, R.A.; Paradiso, A.M. L-Glutamine and L-asparagine stimulate $\mathrm{Na}^{+}-\mathrm{H}^{+}$exchange in porcine jejunal enterocytes. Am. J. Physiol. Gastrointest. Liver Physiol. 1994, 266, 828-838. [CrossRef]

50. Wang, J.; Hu, G.D.; Lin, Z.; He, L.; Xu, L.; Zhang, Y.M. Characteristic and functional analysis of a newly established porcine small intestinal epithelial cell line. PLoS ONE 2014, 9, e110916. [CrossRef]

(C) 2019 by the authors. Licensee MDPI, Basel, Switzerland. This article is an open access article distributed under the terms and conditions of the Creative Commons Attribution (CC BY) license (http:/ / creativecommons.org/licenses/by/4.0/). 